\title{
TRENDS IN TOBACCO-RELATED BEHAVIOUR AMONG YOUNG PEOPLE IN POLAND FROM 1995 TO 2015 AGAINST A BACKGROUND OF SELECTED EUROPEAN COUNTRIES
}

\section{ZMIANY W ZACHOWANIACH ZWIAZZANYCH Z UŻYWANIEM TYTONIU WŚRÓD MŁODZIEŻY W POLSCE W LATACH 1995-2015 NA TLE WYBRANYCH KRAJÓW EUROPEJSKICH}

Katarzyna Dąbrowska, Janusz Sierosławski, Łukasz Wieczorek

Institute of Psychiatry and Neurology, Department of Studies on Alcoholism and Drug Dependence, Warsaw, Poland Instytut Psychiatrii i Neurologii, Zakład Badań nad Alkoholizmem i Toksykomaniami, Warszawa, Polska

Alcohol Drug Addict 2018; 31 (1): 65-82 DOI: https://doi.org/10.5114/ain.2018.78816

\begin{abstract}
Introduction: In 2015, one quarter of Polish residents aged over 15 years smoked every day (24\%). The percentage of smokers is slightly smaller than in previous editions of the study. Despite consistent policy to reduce smoking, the percentage of smokers in the adult population is still quite high. The aim of this study is to follow the trends of smoking and availability of tobacco based on the results of the European School Survey Project on Alcohol and Other Drugs (ESPAD) between 1995 and 2015. Material and methods: For the purposes of the article, a secondary analysis of ESPAD data collected in Poland, the Czech Republic, Italy, Norway and Great Britain was conducted.
\end{abstract}

\section{Streszczenie}

Wprowadzenie: W 2015 roku codziennie paliła jedna czwarta mieszkańców Polski w wieku powyżej 15. roku życia (24\%). Odsetek palaczy jest nieznacznie mniejszy niż w poprzednich edycjach badania. Mimo prowadzonej konsekwentnie polityki na rzecz ograniczenia palenia, odsetek palaczy w populacji osób dorosłych jest wciąż dość wysoki. Celem opracowania jest prześledzenie zmian w paleniu tytoniu i w dostępności tytoniu wśród młodzieży szkolnej na podstawie wyników pomiarów dokonanych $\mathrm{w}$ ramach Europejskiego Programu Badań Ankietowych w Szkołach na temat Alkoholu i innych Substancji Psychoaktywnych (ESPAD) w latach 1995-2015.

Correspondence to/Adres do korespondencji: Katarzyna Dąbrowska, Zakład Badań nad Alkoholizmem i Toksykomaniami, Instytut Psychiatrii i Neurologii, ul. Sobieskiego 9, 02-957 Warszawa, phone: 48224582 739, e-mail: dabrow@ipin.edu.pl

Authors' contribution/Wkład pracy autorów: Study design/Koncepcja badania: K. Dąbrowska, Ł. Wieczorek; Data collection/ Zebranie danych: K. Dąbrowska, J. Sierosławski, Ł. Wieczorek; Statistical analysis/Analiza statystyczna: $Ł$. Wieczorek; Data interpretation/ Interpretacja danych: K. Dąbrowska; Acceptance of final manuscript version/Akceptacja ostatecznej wersji pracy: K. Dąbrowska, J. Sierosławski, Ł. Wieczorek; Literature Search/Przygotowanie literatury: K. Dąbrowska; Funds collection/Pozyskanie środków (finansowania): J. Sierosławski

No ghostwriting and guest authorship declared./Nie występują zjawiska ghostwriting i guest authorship.

Submitted/Otrzymano: 09.04.2018 • Accepted/Przyjęto do druku: 06.08.2018 
Results: Current tobacco use in Poland in 2015 was recorded at $24.8 \%$, which means a decrease by $7.2 \%$ compared to 1999 , the year of the highest smoking prevalence $(32 \%)$. The highest percentage of smokers during 30 days preceding the survey was recorded in Italy (37.1\%). In Norway a spectacular reduction in the percentage of people smoking cigarettes during 30 days preceding the survey was observed from $35.5 \%$ in 1995 to $9.7 \%$ in 2015.

Discussion: The decline in the use of tobacco by young people observed in Poland is in line with the trend observed in other European countries. These positive changes can be, among other things, attributed to the implementation by most states of recommendations resulting from the WHO Framework Convention on Tobacco Control. The strategy that probably played the most important role in the case of young people was the increase in the prices of tobacco products.

Conclusions: It seems that a consistently pursued policy aimed at limiting the use of tobacco brings desirable results in the case of young people. However, it should be noted that, in addition to the policy of limiting the availability of tobacco, the impact on changes in tobacco-related behaviour may have wider cultural and social changes.

Keywords: Trends, ESPAD study, Young people, Cigarettes smoking
Materiał i metody: Na potrzeby artykułu dokonano wtórnej analizy danych zgromadzonych w ramach pomiarów ESPAD przeprowadzonych w Polsce oraz w Czechach, we Włoszech, w Norwegii i Wielkiej Brytanii.

Wyniki: Aktualne używanie tytoniu w Polsce w 2015 roku kształtowało się na poziomie $24,8 \%$, co oznacza spadek o 7,2 punktu procentowego w stosunku do roku 1999, w którym to odnotowano najwyższe rozpowszechnienie palenia. Najwyższy odsetek osób palących w ciągu 30 dni poprzedzających badanie odnotowano we Włoszech $(37,1 \%)$. Spektakularne zmniejszenie odsetka osób sięgających po papierosy w ciągu 30 dni poprzedzających badanie zaobserwowano w Norwegii: z 35,5\% w 1995 roku do 9,7\% w 2015 roku.

Omówienie: Trend spadkowy w używaniu tytoniu przez młodzież w Polsce jest zgodny $\mathrm{z}$ trendem zaobserwowanym w innych krajach europejskich. Pozytywne zmiany można przypisywać m.in. wdrożeniu przez większość państw zaleceń wynikających z Ramowej Konwencji WHO o Ograniczeniu Użycia Tytoniu. Działaniem, które prawdopodobnie odegrało największą rolę w przypadku osób młodych, było zwiększenie cen wyrobów tytoniowych.

Wnioski: Wydaje się, że prowadzona konsekwentnie polityka mająca na celu ograniczanie używania tytoniu przynosi pożądane rezultaty w przypadku młodzieży. Trzeba jednak zauważyć, że oprócz polityki ograniczania dostępności tytoniu, na zmiany $\mathrm{w}$ zachowaniach związanych $\mathrm{z}$ jego konsumpcją mogą mieć wpływ szersze zmiany kulturowe i społeczne.

Słowa kluczowe: trendy, badanie ESPAD, młodzież, palenie papierosów

\section{- INTRODUCTION}

The use, trade and production of tobacco products is in Poland regulated by the law on the protection of health from the consequences of tobacco and tobacco product use of $9^{\text {th }}$ November 1995 [1], which includes:

- a list of places where tobacco smoking is prohibited,

- regulations of the sale, advertising, promotion and sponsoring of tobacco products,

\section{WrRoWAdZeniE}

W Polsce zagadnienia związane z używaniem, handlem i produkcją wyrobów tytoniowych reguluje Ustawa z dnia 9 listopada 1995 r. o ochronie zdrowia przed następstwami używania tytoniu i wyrobów tytoniowych [1], która zawiera:

- wykaz miejsc objętych zakazem palenia wyrobów tytoniowych,

- przepisy dotyczące sprzedaży, reklamy, promocji i sponsorowania wyrobów tytoniowych, 
- requirements concerning tobacco product producers' or importers' reporting on additives used in the production of these products and their quantities,

- requirements concerning the information and health warnings printed on tobacco product packaging.

In 2015, one in four (24\%) Poles over the age of 15 declared they were daily smokers. This reflects a decreasing trend in habitual smokers in relation to previous measurements by 4 per cent in 2013 (vs. 2011) and 3 per cent in 2015 (vs. 2013). Compared to previous editions of the study conducted in 2009, 2011 and 2013, the percentage of declared smokers is slightly smaller [2].

In 2013, nearly half of respondents (45\%) reported that there was someone in their household who smoked tobacco. The percentage recorded in 2015 was smaller by $6 \%$. The study also diagnosed whether it was acceptable to smoke in the whole house or only in specific rooms. In 2015, most respondents declared (18\%), that in their houses, smoking only took place outside, e.g. on the balcony, and next most frequently in the whole home $(13 \%)$ and in rooms designated specially for that purpose (8\%) [2].

The proportion of adult smokers in the population is still quite high despite many years of restrictions on smoking in public places and the scope for advertising tobacco products, and also the requirement to print warnings on tobacco product packaging.

In the course of maturation of young people, risks behaviours occur and increase in frequency, the effects of which may be observed in later years of life. A systematic review of the literature reveals a range of environmental, socio-demographic and individual factors linked to tobacco smoking initiation [3]. In particular, the peer group plays an important role in the formation of behaviour related to tobacco use. The theoretical bases for explaining this phenomenon are, among others, social impact theory and the theory of social learning. These allow prediction of whether young people will try smoking in the course of socialisation [4]. Other factors that encourage risk behaviour include low motivation to achieve success in various areas of life and poor educational results [5]. Kowalewska and Dziels$\mathrm{ka}$ [6], in their discussion of young persons' risk behaviour indicate a biopsychosocial model ex-
- wymogi dotyczące raportowania przez producentów lub importerów wyrobów tytoniowych na temat dodatków używanych do produkcji tych wyrobów i ich ilości,

- wymogi dotyczące informacji i ostrzeżeń zdrowotnych, umieszczanych na opakowaniach wyrobów tytoniowych.

W 2015 roku codzienne palenie zadeklarował co czwarty mieszkaniec Polski w wieku powyżej 15 lat - 24\%. Oznacza to tendencję spadkową osób palących nałogowo $\mathrm{w}$ stosunku do poprzednich pomiarów o 4 punkty procentowe w 2013 roku (vs 2011) i 3 punkty procentowe w 2015 (vs 2013). W porównaniu z poprzednimi edycjami badania, które zostały zrealizowane w latach 2009, 2011 i 2013, odsetek osób deklarujących palenie jest nieznacznie mniejszy [2].

W 2013 roku blisko połowa badanych (45\%) przyznała, że ktoś z ich domowników pali tytoń. Odnotowany w 2015 roku odsetek był mniejszy o 6 punktów procentowych. W badaniu również diagnozowano, czy akceptowane jest palenie tytoniu w całym domu czy tylko w poszczególnych pomieszczeniach. Najwięcej osób w 2015 roku, bo $18 \%$, zadeklarowało, że w ich domach pali się tylko na zewnątrz, np. na balkonie, w następnej kolejności w całym domu - $13 \%$, oraz w wyznaczonych do tego celu pomieszczeniach $-8 \%$ [2].

Pomimo wprowadzanych od wielu lat ograniczeń dotyczących palenia tytoniu w miejscach publicznych i możliwości reklamowania produktów tytoniowych, a także konieczności umieszczania ostrzeżeń na opakowaniach wyrobów tytoniowych, odsetek palaczy w populacji osób dorosłych jest wciąż dość wysoki.

W okresie dorastania u młodzieży pojawiają się i nasilają zachowania ryzykowne, których skutki można zaobserwować w dalszych latach życia. Systematyczny przegląd literatury ujawnia szereg czynników środowiskowych, socjodemograficznych i jednostkowych powiązanych $\mathrm{z}$ inicjacją palenia tytoniu [3]. W szczególności grupa rówieśnicza odgrywa ważną rolę w kształtowaniu zachowań związanych $\mathrm{z}$ używaniem tytoniu. Teoretyczne podstawy wyjaśniające wspomniane zjawisko to m.in. teoria wpływu społecznego i teoria społecznego uczenia się. Pozwalają one przewidywać, czy młodzi ludzie w ramach procesu socjalizacji będą podejmować próby palenia [4]. Inne czynniki, które skłaniają do zachowań ryzykowanych, to niska motywacja do osiągania sukcesów w różnych dziedzinach życia oraz słabe wyniki w nauce [5]. Kowalewska i Dzielska [6], omawiając najnowszą wiedzę na temat ryzykownych 
plaining behaviours of this kind. Biological factors that encourage exposure to risk at a young age are male gender, genetic predisposition and hormonal effects while the psychological factors are thrill-seeking, depression and low self-esteem. Social and environmental factors include errors in upbringing by parents or carer adults, modelling of risk behaviour of parents/adult significant others, peer behaviour and social status. Difficult life situations may increase the propensity to risk behaviour. One of the more common risk behaviours in this time of life is tobacco smoking.

The aim of this paper is to track the changes in tobacco smoking by school children between 15 and 16 years of age on the basis of the results of the ESPAD study in Poland between 1995 and 2015. This article also analyses the changes that have taken place in the perception of the availability of cigarettes and the age of tobacco initiation in the population covered by the ESPAD study.

The main emphasis shall be on changes in the use of tobacco by young people in Poland. In order to illustrate the situation in this country, the data from four other European countries was also presented: i.e. the Czech Republic, Italy, Norway and Great Britain. These countries were selected because, firstly, the study was conducted similarly to how it has been in Poland since 1995, and secondly, all measurements were taken with the exception of that of the UK in 2015. These are also countries in which tobacco smoking among young people is differentiated as shall be shown in further in the article.

\section{- Material and methods}

The methodology of the international study ESPAD was described in a different article [7]. The purpose of the ESPAD study is to monitor the use of psychoactive substances by school children and their other risk behaviours. The studied population were students from one year of 15 to 16 years of age at the time of the study. The sampling frame is a list of schools drawn up by the Ministry of Education containing information on the number of classes in each of the schools. The sampling scheme selection assumes a two-stage random selection. First schools are selected and then classes in the second stage. The schools selected have zachowań młodzieży, wskazują na model biopsychospołeczny podejmowania takich zachowań. Czynnikami biologicznymi, które sprzyjają narażaniu się na ryzyko w młodym wieku, są płeć męska, predyspozycje genetyczne i wpływy hormonalne, zaś czynnikami psychologicznymi - poszukiwanie wrażeń, depresja, niska samoocena. Czynniki społeczne i środowiskowe obejmują błędy wychowawcze popełniane przez rodziców bądź opiekunów, modelowanie ryzykownych zachowań przez rodziców/dorosłe osoby znaczące, zachowania rówieśników, status społeczny. Trudne sytuacje życiowe mogą zwiększać podatność na zachowania ryzykowne. Jednym z dość powszechnych zachowań ryzykownych w tym okresie jest palenie tytoniu.

Celem tego opracowania jest prześledzenie zmian $\mathrm{w}$ paleniu tytoniu przez młodzież szkolną w wieku 15-16 lat, na podstawie wyników badania ESPAD w latach 1995-2015 w Polsce. Artykuł ten dodatkowo analizuje zmiany, jakie zaszły w postrzeganiu dostępności papierosów oraz w wieku inicjacji tytoniowej w populacji objętej badaniem ESPAD.

Główny nacisk zostanie położony na zmiany $\mathrm{w}$ zachowaniach związanych z używaniem tytoniu wśród młodzieży w Polsce. Dla zilustrowania sytuacji w naszym kraju zaprezentowane zostały również dane z czterech innych krajów europejskich: Czech, Włoch, Norwegii i Wielkiej Brytanii. Zostały one wybrane, ponieważ, po pierwsze, badanie ESPAD w tych krajach było prowadzone podobnie jak w Polsce od 1995 roku, a po drugie, przeprowadzono tam wszystkie pomiary, z wyjątkiem pomiaru z $2015 \mathrm{w}$ Wielkiej Brytanii. Są to również kraje, w których palenie tytoniu wśród młodzieży ma zróżnicowaną charakterystykę, co zostanie wykazane w dalszej części artykułu.

\section{- Materiat I metody}

Metodologia międzynarodowego badania ESPAD została opisana w innym artykule [7]. Celem badania ESPAD jest monitorowanie używania substancji psychoaktywnych przez młodzież szkolną oraz innych zachowań ryzykownych. Badana populacja to uczniowie $\mathrm{z}$ jednego rocznika w wieku 15-16 lat w chwili badania. Operatem losowania jest lista szkół sporządzona przez Ministerstwo Edukacji Narodowej, zawierająca informacje o liczbie klas w każdej ze szkół. Schemat doboru zakłada losowy dobór dwustopniowy. W pierwszej kolejności losowane są szkoły, a następnie klasy. Szkoły losuje się 
probabilities proportional to the number of classes so that all classes have identical chances of being in the sample irrespective of the size of school from which they originate. The classes are picked by simple random selection with one class from each of the selected schools.

All the students who had agreed to participate and present on the day in a selected class took part in the study. It was accepted that the student sample should not be fewer than 2400 in order to ensure survey representativeness. The survey is realised in auditory manner in the school classrooms with the use of a self-administered questionnaire.

A secondary analysis was conducted for the purposes of this article on the data collected in all the ESPAD editions conducted in Poland as well as in the Czech Republic, Italy, Norway and Great Britain. The differentiation for each country as regards the year of edition was tested with the chi-square test.

The chosen indicators concerned perceived availability of cigarettes, young persons' lifetime experiences with cigarettes, current tobacco use by young people (cigarette use within the 30 days preceding the survey irrespective of the frequency of smoking during this time is here interpreted as current use) and the age of smoking initiation. Apart from data on use, it was decided to present data on tobacco availability as studies on young people show that if they perceive access to illicit substances as easy, they are more likely to purchase and experiment [8]. The perception of tobacco as easily available increases the risk of both smoking initiation and regular use [9-11].

Survey answers were aggregated to facilitate the following of trends in young people's behaviour. The cafeteria concerning question on the availability of cigarettes includes the answers "impossible", "very hard", "rather difficult", "rather easy", "very easy" and "difficult to say". All the answers indicating that it was impossible to get hold of cigarettes or that access was difficult were aggregated to one category like all answers indicating easy access to cigarettes. The answer "difficult to say" was analysed separately. The original cafeteria of question about how often a respondent used cigarettes in the last 12 months was as follows: „0”, „1-2”, „3-5”, „6-9”, „10-19”, "20-39", „40 or more". The two extreme categories z prawdopodobieństwami proporcjonalnymi do liczby klas tak, aby wszystkie klasy miały jednakowe szanse trafienia do próby, niezależnie od wielkości szkoły, z której się rekrutują. Klasy dobierane są w losowaniu prostym, po jednej klasie w każdej z wylosowanych szkół.

W badaniu brali udział wszyscy uczniowie wylosowanej klasy obecni w dniu badania w szkole, którzy zgodzili się na udział w nim. Przyjęto, że próba nie powinna być mniejsza niż 2400 uczniów, co zapewnia reprezentatywność badania. Badanie jest realizowane audytoryjnie w klasach szkolnych, z wykorzystaniem kwestionariusza do samodzielnego wypełnienia.

Na potrzeby artykułu dokonano wtórnej analizy danych zgromadzonych we wszystkich pomiarach ESPAD przeprowadzonych w Polsce oraz w Czechach, Włoszech, Norwegii i Wielkiej Brytanii. Dla każdego kraju zróżnicowanie ze względu na rok pomiaru było testowane testem chi-kwadrat.

Wybrano wskaźniki dotyczące postrzeganej dostępności papierosów, doświadczeń młodzieży z papierosami w okresie życia, aktualnego używania papierosów przez młodzież (używanie papierosów w ciągu 30 dni poprzedzających badanie, bez względu na częstotliwość palenia $\mathrm{w}$ tym okresie, interpretowane jest tu jako aktualne używanie), wieku inicjacji palenia. Oprócz danych na temat używania zdecydowano się zaprezentować dane odnoszące się do dostępności papierosów, gdyż jak pokazują badania, młodzi ludzie, którzy postrzegają dostęp do nielegalnych substancji jako łatwy, z większym prawdopodobieństwem będą je nabywali i eksperymentowali z nimi [8]. Postrzeganie tytoniu jako łatwo dostępnego zwiększa ryzyko zarówno inicjacji palenia, jak i regularnego używania [9-11].

Odpowiedzi na pytania zostały zagregowane po to, by łatwiej było prześledzić trendy w zachowaniach młodzieży. Kafeteria dotycząca pytania o możliwość zdobycia papierosów obejmuje odpowiedzi: „niemożliwe”, „bardzo trudne”, „raczej trudne”, „raczej łatwe”, „bardzo łatwe”, „trudno powiedzieć”. Wszystkie odpowiedzi wskazujące na niemożność zdobycia papierosów lub trudność w ich zdobyciu zagregowano do jednej kategorii, podobnie jak wszystkie odpowiedzi wskazujące na łatwość w dostępie do papierosów. Odpowiedź „trudno powiedzieć” była analizowana osobno. Oryginalna kafeteria odnosząca się do pytania, jak często respondent używał papierosów w ciągu ostatnich 12 miesięcy, wyglądała następująco: „0", „1-2”, „3-5”, „6-9”, „10-19”, ,20-39”, 
of answers remained unchanged. The remaining were formed into two categories from " $1-9$ " and "10-39". Respondents' answers about smoking in the last 30 days were also aggregated. All the positive answers irrespective of smoking frequency were collected into the category "yes". The possible frequencies were "less than one cigarette per week", "less than one cigarette per day", "1 to 5 cigarettes per day", " 6 to 10 cigarettes per day", "11 to 20 cigarettes per day" and "more than 20 cigarettes per day". As regards questions on the initiation of smoking, respondents could choose between nine answers for which the lower limit of initiation was set at smoking the first cigarette at the age of 9 or less and the upper at 16 or more. It was also possible to answer that there had never been an initiation. The answers were aggregated into four positions from "never", "11 or less", "12-14" to "15 or more".

\section{- Results}

\section{Assessment of the availability of cigarettes}

The perception of a substance's availability is a significant factor that may influence its use. In Table I, we present the results concerning the availability of cigarettes according to the respondents in the countries selected for analysis. Between 1999 and 2015 there was an increase from 5.8\% to $15.6 \%$ in the proportion of people who assessed access to cigarettes as either impossible of difficult in Poland. At the same time, the percentage believing that access to cigarettes was easy decreased from $90.5 \%$ to $73.1 \%$. The largest decline of almost 15\% was observed between 2003 and 2007. The proportion of people who found it difficult to judge the availability of cigarettes increased from $3.8 \%$ to $11.2 \%$. This might be due to ever fewer young people experimenting with cigarettes.

In 1995, Poland had the highest proportion of respondents judging that access to cigarettes was impossible or difficult, followed by Great Britain. The smallest proportion was reported in the Czech Republic at $1.6 \%$. In 2015, the greatest percentage of respondents who judged access to cigarettes as impossible or difficult was recorded in Italy, and the smallest in the Czech republic. There was a significant change in all countries from 2003 to 2007.
„40 i więcej”. Dwie skrajne kategorie odpowiedzi pozostawiono bez zmian. Z pozostałych utworzono natomiast dwie nowe kategorie: „1-9” i „10-39”. Zagregowano również odpowiedzi respondentów na pytanie o palenie w czasie ostatnich $30 \mathrm{dni}$. Wszystkie odpowiedzi pozytywne, bez względu na częstotliwość palenia, zostały zagregowane do jednej kategorii „tak”. Możliwe do wyboru częstotliwości to: „palenie mniej niż 1 papierosa na tydzień”, „palenie mniej niż 1 papierosa na dzień”, „palenie od 1 do 5 papierosów na dzień”, „palenie od 6 do 10 papierosów na dzień”, „palenie od 11 do 20 papierosów na dzień”, „palenie więcej niż 20 papierosów na dzień”. Jeśli chodzi o pytanie o inicjację palenia, respondenci mieli do wyboru dziewięć odpowiedzi, gdzie dolną granicę inicjacji wyznaczało wypalenie pierwszego papierosa w wieku 9 lat lub mniej, a górną - w wieku 16 lat lub więcej. Możliwa była również odpowiedź oznaczająca, że do inicjacji nie doszło. Odpowiedzi zagregowano do czterech pozycji: „nigdy”, „11 lat lub mniej”, „12-14 lat”, „15 lat i więcej”.

\section{- WYNIKI}

\section{Ocena dostępności papierosów}

Postrzegana dostępność substancji jest istotnym czynnikiem, który może wpływać na jej używanie. W tabeli I zaprezentowano wyniki dotyczące dostępności papierosów w ocenie badanych $\mathrm{w}$ wybranych do analizy krajach. W Polsce pomiędzy rokiem 1999 a 2015 wzrósł z 5,8\% do 15,6\% odsetek osób, w których ocenie zdobycie papierosów byłoby niemożliwe lub trudne. Jednocześnie z $90,5 \%$ do 73,1\% spadł odsetek osób, które uważają, że zdobycie papierosów byłoby łatwe. Największy spadek obserwujemy pomiędzy rokiem 2003 a 2007, blisko o 15 punktów procentowych. Z 3,8\% do 11,2\% zwiększył się odsetek osób, którym trudno ocenić dostępność papierosów. Być może jest to związane z tym, że coraz mniej młodzieży podejmuje takie próby.

W 1995 roku Polska miała wśród analizowanych krajów najwyższy odsetek osób oceniających zdobycie papierosów jako niemożliwe lub trudne, zaraz za nią plasowała się Wielka Brytania. Najniższy odsetek osób stwierdzono w Czechach $(1,6 \%)$. W 2015 roku najwyższy odsetek respondentów, którzy oceniali dostęp do papierosów jako niemożliwy lub trudny, odnotowano we Włoszech, a najniższy w Czechach. We wszystkich krajach znacząca zmiana zaszła pomiędzy rokiem 2003 a 2007. 


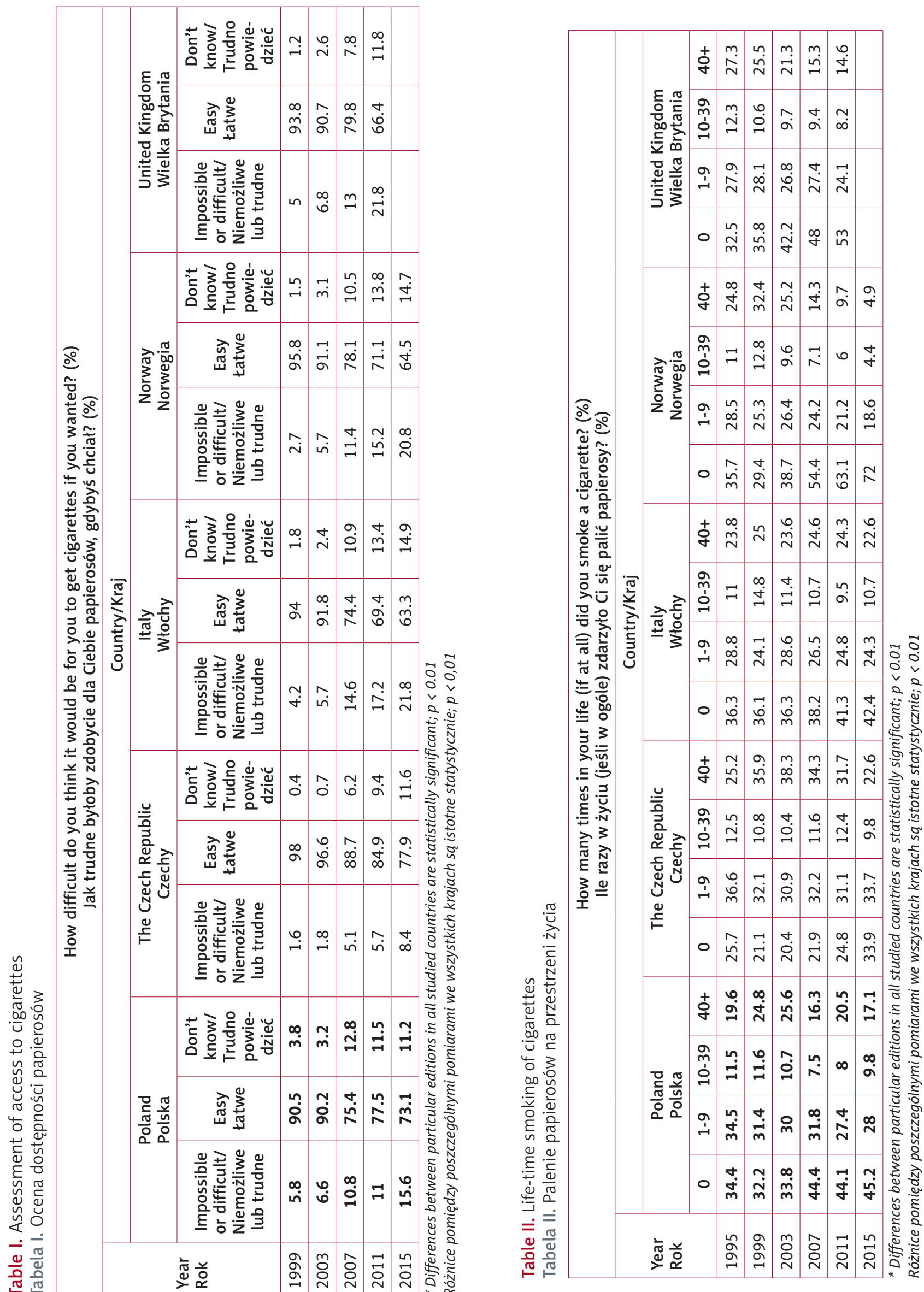


Table III. Smoking during 30 days preceding the study

Tabela III. Palenie papierosów w okresie 30 dni poprzedzających badanie

\begin{tabular}{|c|c|c|c|c|c|c|c|c|c|c|}
\hline \multicolumn{11}{|c|}{$\begin{array}{l}\text { Did you smoke cigarettes during } 30 \text { days preceding the study? (\%) } \\
\text { Czy paliłeś papierosy w ciągu } 30 \text { dni poprzedzających badanie? (\%) }\end{array}$} \\
\hline \multirow{3}{*}{$\begin{array}{l}\text { Year } \\
\text { Rok }\end{array}$} & \multicolumn{10}{|c|}{ Country/Kraj } \\
\hline & \multicolumn{2}{|c|}{$\begin{array}{l}\text { Poland } \\
\text { Polska }\end{array}$} & \multicolumn{2}{|c|}{$\begin{array}{c}\text { The Czech Republic } \\
\text { Czechy }\end{array}$} & \multicolumn{2}{|c|}{$\begin{array}{c}\text { Italy } \\
\text { Włochy }\end{array}$} & \multicolumn{2}{|c|}{$\begin{array}{l}\text { Norway } \\
\text { Norwegia }\end{array}$} & \multicolumn{2}{|c|}{$\begin{array}{l}\text { United Kingdom } \\
\text { Wielka Brytania }\end{array}$} \\
\hline & No/Nie & Yes/Tak & No/Nie & Yes/Tak & No/Nie & Yes/Tak & No/Nie & Yes/Tak & No/Nie & Yes/Tak \\
\hline 1995 & 72.1 & 27.9 & 66.1 & 33.9 & 64.8 & 35.2 & 64.5 & 35.5 & 64.2 & 35.8 \\
\hline 1999 & 68 & 32 & 55.7 & 44.3 & 60.3 & 39.7 & 60.3 & 39.7 & 66.2 & 33.8 \\
\hline 2003 & 70 & 30 & 57.2 & 42.8 & 63.5 & 36.5 & 72.6 & 27.4 & 71 & 29 \\
\hline 2007 & 79.2 & 20.8 & 59.3 & 40.7 & 62.7 & 37.3 & 80.7 & 19.3 & 78.5 & 21.5 \\
\hline 2011 & 71.6 & 28.4 & 57.7 & 42.3 & 63.5 & 36.5 & 85.8 & 14.2 & 76.8 & 23.2 \\
\hline 2015 & 75.2 & 24.8 & 70.2 & 29.8 & 62.9 & 37.1 & 90.3 & 9.7 & & \\
\hline
\end{tabular}

${ }^{*}$ Differences between particular editions in all studied countries are statistically significant; $p<0.01$

Różnice pomiędzy poszczególnymi pomiarami we wszystkich krajach są istotne statystycznie; $p<0,01$

\section{Life-time experience of smoking cigarettes}

The ESPAD study diagnoses the frequency of young persons' life-time experiences with cigarettes (Table II). In 2015, the percentage of persons in Poland who had never smoked cigarettes was $45 \%$. This was an increase of almost $11 \%$ in relation to 1995 (34.4\%). There was also observed a decrease in the number of smokers who had smoked more than 40 times in their lives from $19.6 \%$ in 1995 to $17.1 \%$ in 2015 . This decrease was not however so large $(2.5 \%)$ as the increase in the percentage of persons who had never smoked at all.

The largest recorded increase between 1995 and 2015 for the percentage of persons who had never smoked was in Norway. In Norway also was observed the greatest decrease in the percentage of those who had smoked more than 40 times from $24.8 \%$ to $4.9 \%$, while in Italy there was only a small decrease of $1.2 \%$.

Cigarette smoking 30 days preceding

the survey

The ESPAD study considers persons who declared they had smoked within 30 days prior to the survey as current tobacco users (Table III). In Poland, $72 \%$ of young persons declared that they had not smoked cigarettes 30 days prior to the study in 1995. Between 1995 and 2015, the proportion of respondents who had not smoked 30 days prior to the study increased by $3.1 \%$. This increase has not however

\section{Doświadczenia z paleniem papierosów na przestrzeni życia}

W badaniu ESPAD diagnozowane jest nasilenie doświadczeń młodzieży z papierosami w okresie życia (tab. II). W 2015 roku frakcja osób w Polsce, które nigdy nie sięgnęły po papierosy, kształtowała się na poziomie $45 \%$. Oznacza to wzrost o blisko 11 punktów procentowych w stosunku do 1995 roku $(34,4 \%)$. Zaobserwowano również spadek odsetka osób, które paliły ponad 40 razy w życiu - z 19,6\% w roku 1995 do 17,1\% w 2015. Spadek ten nie był jednak tak duży (jedynie 2,5 punktu procentowego) jak wzrost frakcji osób niesięgających po papierosy.

Największy wzrost pomiędzy rokiem 1995 a 2015 odsetka osób, które dotychczas nie sięgnęły po papierosy, można zaobserwować w Norwegii. W Norwegii nastąpił największy spadek we frakcji osób, które w latach 1995-2015 sięgnęły po papierosy ponad 40 razy (z $24,8 \%$ do $4,9 \%$ ), natomiast we Włoszech - bardzo niewielki spadek odsetka takich osób, tj. o 1,2 punktu procentowego.

\section{Używanie papierosów w okresie 30 dni poprzedzających badanie}

W badaniu ESPAD osoby, które zadeklarowały palenie w ciągu 30 dni poprzedzających badanie, uznawane są za aktualnych użytkowników tej substancji (tab. III). W Polsce w 1995 roku 72\% młodzieży zadeklarowało, że w ciągu 30 dni poprzedzających badanie nie sięgało po papierosy. Pomiędzy rokiem 1995 a 2015 odsetek osób, które nie paliły w ciągu ostatnich 30 dni, wzrósł o 3,1\%. Jednak wzrost ten 


\begin{tabular}{|c|c|c|c|c|c|c|c|c|c|c|}
\hline \multirow{21}{*}{ 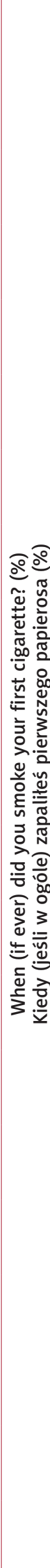 } & \multirow{4}{*}{ : } & \multirow{4}{*}{ 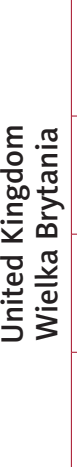 } & 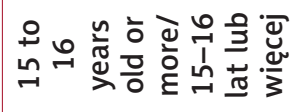 & 0 & $\begin{array}{l}\infty \\
\dot{\sim} \\
\dot{1}\end{array}$ & $\overrightarrow{0}$ & \begin{tabular}{l|}
$\infty$ \\
$\infty$ \\
$\infty$
\end{tabular} & $\begin{array}{l}\infty \\
0 \\
0 \\
\sim\end{array}$ & & \\
\hline & & & 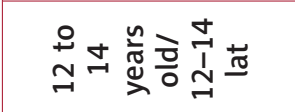 & $\stackrel{\sim}{\vec{q}}$ & $\begin{array}{l}\infty \\
\stackrel{⿲}{m}\end{array}$ & $\stackrel{\substack{n \\
\infty \\
m}}{m}$ & $\underset{m}{m}$ & 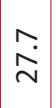 & & \\
\hline & & & 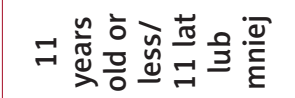 & $\stackrel{\sim}{2}$ & $\begin{array}{l}0 \\
\infty \\
\rightarrow \\
-1\end{array}$ & $\stackrel{m}{m}$ & $\stackrel{\sim}{\sim}$ & $\vec{a}$ & & \\
\hline & & & 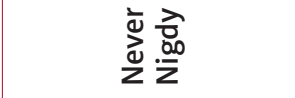 & $\underset{\mathrm{q}}{\mathrm{m}}$ & $\begin{array}{l}\infty \\
\stackrel{n}{m} \\
\dot{m}\end{array}$ & 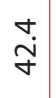 & $\begin{array}{l}a \\
\dot{q} \\
\dot{y}\end{array}$ & $\stackrel{n}{i n}$ & & \\
\hline & & 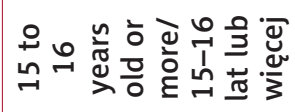 & $\begin{array}{l}\infty \\
\infty \\
\infty\end{array}$ & $\stackrel{n}{a}$ & बrạ & $\underset{\infty}{+}$ & $\begin{array}{l}\sigma \\
\infty\end{array}$ & $\begin{array}{l}0 \\
\dot{0}\end{array}$ & \\
\hline & & & 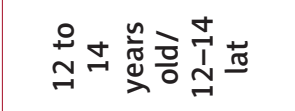 & $\hat{\dot{\omega}}$ & $\hat{\ddot{q}}$ & $\stackrel{\mathrm{m}}{ }$ & $\begin{array}{l}0 \\
\ddot{\sim} \\
\dot{\sim}\end{array}$ & $\begin{array}{c}\hat{\infty} \\
\rightarrow \\
-1\end{array}$ & $\begin{array}{l}\hat{\text { n் }} \\
\stackrel{n}{n}\end{array}$ & \\
\hline & & & 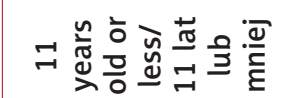 & $\stackrel{\infty}{\rightarrow}$ & $\overrightarrow{\ddot{6}}$ & $\stackrel{+}{\stackrel{+}{+}}$ & $\begin{array}{l}\infty \\
\ddot{m} \\
\sim\end{array}$ & $\stackrel{+}{\sigma}$ & in & \\
\hline & & 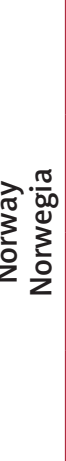 & 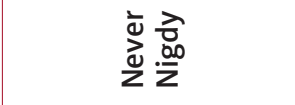 & 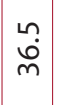 & $\hat{i}$ & $\begin{array}{l}\infty \\
\dot{o} \\
\dot{q}\end{array}$ & $\stackrel{\sim}{\stackrel{\sim}{n}}$ & $\overrightarrow{\tilde{n}}$ & $\stackrel{9}{i}$ & \\
\hline & \multirow{4}{*}{. } & \multirow{4}{*}{ 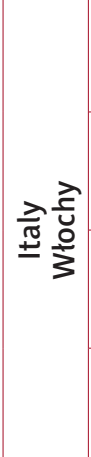 } & 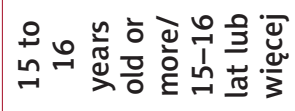 & $\begin{array}{l}\stackrel{0}{\leftrightarrow} \\
\sim\end{array}$ & $\underset{+}{\stackrel{-}{ \pm}}$ & 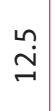 & $\overrightarrow{0}$ & $\hat{\omega}$ & $\stackrel{n}{\stackrel{n}{ }}$ & \\
\hline & & & 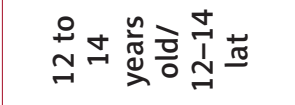 & ণें & $\stackrel{\sim}{\stackrel{y}{\sim}}$ & $\begin{array}{l}\stackrel{0}{\tilde{r}} \\
\dot{\sigma}\end{array}$ & $\underset{\forall}{\forall}$ & $\begin{array}{l}m \\
\dot{m} \\
m\end{array}$ & $\begin{array}{l}\sim \\
\dot{m} \\
m\end{array}$ & \\
\hline & & & 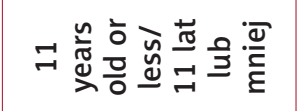 & $\begin{array}{l}\infty \\
\infty \\
\infty\end{array}$ & $\underset{\infty}{n}$ & $\begin{array}{l}\omega_{0} \\
\infty\end{array}$ & Na & $\begin{array}{l}n \\
0 \\
0\end{array}$ & $\stackrel{\leftrightarrow}{+}$ & \\
\hline & & & 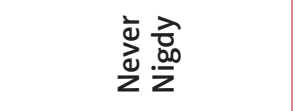 & $\begin{array}{l}m \\
\dot{p} \\
m\end{array}$ & $\stackrel{\sim}{\stackrel{n}{n}}$ & $\stackrel{\dot{r}}{m}$ & $\begin{array}{l}\infty \\
\dot{m} \\
m\end{array}$ & 華 & 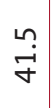 & \\
\hline & & & 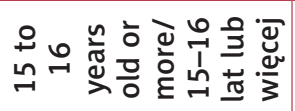 & $\stackrel{\sim}{\underset{\sim}{\sim}}$ & $\stackrel{m}{m}$ & $\stackrel{\substack{n \\
\hdashline}}{\rightarrow}$ & $\stackrel{\sim}{\infty}$ & $\stackrel{+}{\circ}$ & $\stackrel{\circ}{\circ}$ & \\
\hline & & $\begin{array}{l}\overline{0} \\
\overline{0} \\
\frac{0}{a} \\
\ddot{a}\end{array}$ & 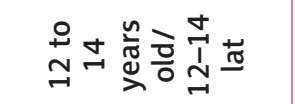 & $\begin{array}{l}n \\
\infty \\
m\end{array}$ & $\stackrel{\infty}{\dot{q}}$ & $\begin{array}{l}\infty \\
\dot{q} \\
\dot{\sigma}\end{array}$ & 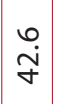 & 우 & $\underset{\dot{\infty}}{\stackrel{+}{m}}$ & \\
\hline & & 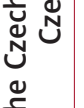 & 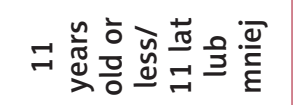 & $\stackrel{\sim}{\sim}$ & 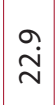 & $\stackrel{a}{\vec{i}}$ & $\begin{array}{c}m \\
\infty \\
\sim \\
\sim\end{array}$ & $\begin{array}{l}\stackrel{n}{0} \\
\stackrel{\rho}{\sim}\end{array}$ & $\stackrel{\infty}{\sim}$ & \\
\hline & & & 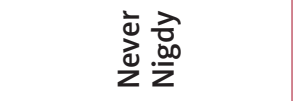 & 文 & $\approx$ & $\begin{array}{l}\infty \\
\stackrel{i}{i}\end{array}$ & o. & $\overrightarrow{\ddot{n}}$ & $\underset{\sim}{\stackrel{0}{m}}$ & \\
\hline & & & 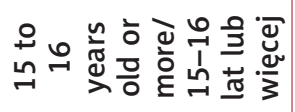 & $\stackrel{\Delta}{-}$ & $\stackrel{\sim}{\underset{i}{\mathfrak{T}}}$ & $\overrightarrow{-}$ & $\begin{array}{c}m \\
\stackrel{m}{\sim} \\
\sim\end{array}$ & กิ่ & กุ่ & \\
\hline & & 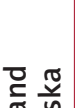 & 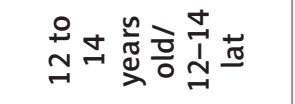 & $\underset{\infty}{\infty}$ & $\begin{array}{c}\infty \\
\dot{m} \\
m\end{array}$ & จิ & ผุ & $\stackrel{i}{i}$ & ஸे & \\
\hline & & ㅇㅇㅇ & 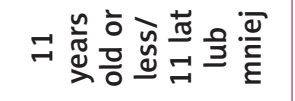 & $\stackrel{0}{\hat{q}}$ & $\begin{array}{l}0 \\
9 \\
9\end{array}$ & ò̀ & 官 & $\underset{\mathfrak{i}}{\stackrel{\sim}{\sim}}$ & 윽 & \\
\hline & & & 离 & ma & $\stackrel{\sim}{n}$ & 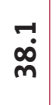 & $\underset{\mathfrak{y}}{\mathscr{y}}$ & J & gे & \\
\hline & & & 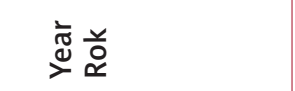 & బू. & よ̀ & ồ & & $\overrightarrow{\vec{D}}$ & $\stackrel{n}{\stackrel{n}{\sim}}$ & \\
\hline
\end{tabular}


been linear. In 1999, the percentage of current cigarette smokers increased from $27.9 \%$ to $32 \%$ and in 2003 , it remained at $30 \%$ only to fall to $20.8 \%$ in 2007 . There was another rise in current cigarette users recorded in 2011, while in 2015 there was another decrease. The smallest recorded percentage of users in the last 30 days was in 2007 at $20.8 \%$. In Poland, the percentage of smokers in 2015 at $24.8 \%$ was at a similar level to that in the United Kingdom recorded in 2011 at $23.2 \%$. The highest proportion of smokers in the 30 days prior to the survey was recorded in Italy in 2015 at $37.1 \%$. In the period 1995 to 2015 , the percentage of smoking young people increased there from $35.2 \%$ to $37.1 \%$. There was a spectacular decrease in the percentage of smokers in the last 30 days in Norway from $35.5 \%$ in 1995 to $9.7 \%$ in 2015 .

\section{Age of initiation}

The age of initiation for the use of various substances is a significant factor that may influence the use of that substance in the future. Table IV presents the age distribution for respondents' first smoked cigarette. In Poland over the 20 years between the first and the last ESPAD edition, the age of initiation increased. While in $1995,17.6 \%$ of respondents had smoked their first cigarette at 11 years of age or less, in 2015 that was only $10 \%$. However, it ought to be noted that up to 2003, the proportion of first-time smokers in that age group increased only to fall from 2007. The most frequent age of initiation for tobacco is 12 to 14 years of age in Poland. In 2015, the greatest percentage of young people who had smoked their first cigarette at 11 or younger was recorded in the Czech Republic at 18\%, though also there between 1995 and 2015 the percentage of respondents who smoked at a young age decreased. The situation looks best in Norway, where the earliest age of initiation group was made up of 5.7\% of respondents. There was also a rather large decrease in the percentage of first-time smokers at the age of 11 or less in the UK between 1995 and 2011 .

\section{- Discussion}

An important aspect of the limitation of psychoactive substance use is the limitation of its nie jest liniowy. W 1999 roku wzrosła frakcja osób używających aktualnie papierosów (z 27,9\% do 32\%) i w 2003 roku utrzymywała się na podobnym poziomie $30 \%$, by w 2007 roku spaść do $20,8 \%$. Ponowny wzrost u osób aktualnie używających papierosów wykazał pomiar w 2011 roku, podczas gdy w 2015 roku znowu odnotowano spadek. Najmniej respondentów zadeklarowało używanie papierosów w ciągu ostatnich 30 dni w 2007 roku - 20,8\%. W Polsce odsetek osób palących oznaczony w 2015 roku $(24,8 \%)$ kształtował się na podobnym poziomie jak zarejestrowany w 2011 roku w Wielkiej Brytanii $(23,2 \%)$. Najwyższy odsetek osób palących w ostatnich 30 dniach zaobserwowano we Włoszech $(37,1 \%)$. W okresie 1995-2015 nastąpił tam wzrost odsetka młodzieży z 35,2\% do 37,1\%. Spektakularne zmniejszenie odsetka osób sięgających po papierosy w ciągu 30 dni poprzedzających badanie stwierdzono w Norwegii: z 35,5\% w roku 1995 do 9,7\% w 2015.

\section{Wiek inicjacji}

Wiek inicjacji używania substancji jest istotnym czynnikiem, który może mieć wpływ na używanie tej substancji w przyszłości. Tabela IV przedstawia rozkład wieku, kiedy respondenci po raz pierwszy zapalili papierosa. W Polsce na przestrzeni 20 lat, które upłynęły pomiędzy pierwszym a ostatnim pomiarem ESPAD, wiek inicjacji podwyższył się. O ile w 1995 roku po pierwszego papierosa sięgnęło $17,6 \%$ respondentów w wieku 11 lat lub młodszych, o tyle w 2015 roku było to już 10\%. Trzeba jednak zauważyć, że do 2003 roku odsetek osób inicjujących palenie w tej grupie wiekowej rósł, by dopiero od 2007 roku spadać. Najczęściej w Polsce do inicjacji tytoniowej dochodzi pomiędzy 12 a 14 rokiem życia. W 2015 roku najwyższy odsetek młodzieży, która zapaliła swojego pierwszego papierosa $\mathrm{w}$ wieku 11 lat lub mniej, odnotowano w Czechach (18\%), choć również tam pomiędzy rokiem 1995 a 2015 spadł odsetek osób, które sięgają po papierosa w tak młodym wieku. Najlepiej sytuacja wygląda w Norwegii, gdzie w najmłodszej grupie wiekowej inicjacji dokonało 5,7\% respondentów. Dość duży spadek odsetka osób sięgających po papierosa w wieku 11 lat lub mniej zaobserwowano również w Wielkiej Brytanii (pomiędzy rokiem 1995 a 2011).

\section{- OmóWIEnIE}

Ważnym aspektem ograniczenia używania substancji psychoaktywnej jest zmniejszenie jej 
availability [12, 13]. In Poland between 1999 and 2015, the percentage of respondents who assessed access to cigarettes as impossible or difficult increased from $5.8 \%$ to $15.6 \%$. At the same time, the percentage of persons who judge that access is easy decreased from 90.5 to $73.1 \%$. The largest decrease was observed between 2003 and 2007 at almost 15\%. We observed a limitation in the availability of cigarettes in all the analysed countries.

In 2015 the percentage of Polish respondents who had never smoked cigarettes was $45 \%$. This represents an increase of almost $11 \%$ in relation to 1995 (34.4\%). The average for all countries participating in the ESPAD study was higher at $54 \%$ [14].

Current use of cigarettes in Poland was $24.8 \%$ in 2015 , which is a decrease of $7.2 \%$ on the highest prevalence in 1999 at 32\%. The possibility of comparing this result with that of other studies is limited due to differing methodologies (studied population, adopted indicators, ways of posing questions and time of the measurement) and also due to various modes of data presentation in the literature available. Despite these differences, we attempted to compare the results gained in ESPAD studies with other surveys on this subject carried out in Poland. The international study Health Behaviour in School-Aged Children (HBSC) within which measurements are conducted every four years showed that from 1990 to 1998 the percentage of 14 and 15 years old boys and girls who smoked every day increased with a small decrease noted in 2002 [15]. The decrease in regular, daily tobacco use in the 14 to 15 -year-old age group started in 2002 and continued until 2010 [16]. Within the ESPAD study, this measurement was conducted in 2003 and this was the first year in which the decreasing tendency in current tobacco use emerged.

In the ESPAD study, a systematic decrease in current tobacco use by young people was observed while the HBSC study noted that between 2010 and 2014 the percentage of 14 and 15-yearolds who declared themselves to be regular smokers (daily or at least once a week) was simi$\operatorname{lar}(13.9 \%$ in 2010 and $15.1 \%$ in 2014). In ESPAD study during approximate period, that is between 2011 and 2015, a decrease was noted from 28.4\% to $24.8 \%$ respectively. dostępności $[12,13]$. W Polsce pomiędzy rokiem 1999 a 2015 wzrósł z 5,8\% do 15,6\% odsetek osób, w których ocenie zdobycie papierosów byłoby niemożliwe lub trudne. Jednocześnie z $90,5 \%$ do $73,1 \%$ spadł odsetek osób, które uważają, że zdobycie papierosów byłoby łatwe. Największy spadek obserwujemy pomiędzy rokiem 2003 a 2007, blisko o 15 punktów procentowych. We wszystkich analizowanych krajach zaobserwowano ograniczenie dostępności papierosów.

W 2015 roku frakcja młodych osób w Polsce, które nigdy nie sięgnęły po papierosy, kształtowała się na poziomie $45 \%$. Oznacza to wzrost tej frakcji o blisko 11 punktów procentowych w stosunku do 1995 roku (34,4\%). Średnia dla wszystkich krajów biorących udział w badaniu ESPAD była wyższa (54\%) [14].

Aktualne używanie papierosów w Polsce w 2015 roku zostało oznaczone na poziomie $24,8 \%$, czyli jest to spadek o 7,2 punktu procentowego $\mathrm{w}$ stosunku do roku 1999, kiedy odnotowano najwyższe rozpowszechnienie, tj. 32\%. Możliwości skonfrontowania tego wyniku z wynikami innych badań są ograniczone ze względu na ich zróżnicowaną metodologię (chodzi m.in. o populację objętą badaniem, przyjęte wskaźniki, sposób zadawania pytań, czas pomiaru), ale także na zróżnicowany sposób prezentowania danych w dostępnych opracowaniach. Pomimo tych różnic podjęto starania porównania wyników uzyskanych w badaniu ESPAD z innymi prowadzonymi w Polsce badaniami o tej tematyce. Międzynarodowe badanie „Zachowania Zdrowotne Młodzieży Szkolnej" (HBSC), w ramach którego pomiar dokonywany jest co cztery lata, wykazało, że od roku 1990 do 1998 zarówno w grupie 14- i 15-letnich chłopców, jak i dziewcząt wzrastał odsetek osób palących codziennie, a niewielki spadek odnotowano w 2002 roku [15]. Spadek regularnego i codziennego używania tytoniu w grupie 14- i 15-latków, który rozpoczął się w roku 2002, trwał do 2010 [16]. W badaniu ESPAD pomiar był prowadzony w 2003 roku i ten rok był pierwszym, w którym ujawniła się tendencja spadkowa w aktualnym używaniu tytoniu.

O ile jednak w badaniu ESPAD obserwowano systematyczny spadek w odsetkach młodzieży aktualnie używającej tytoniu, o tyle badanie HBSC pokazało, że pomiędzy rokiem 2010 a 2014 odsetek młodzieży 14- i 15-letniej, która zadeklarowała regularne palenie (codzienne lub co najmniej raz w tygodniu), był podobny (2010 - 13,9\%; 2014 - 15,1\%) [17]. W badaniu ESPAD w zbliżonym 
Another study "Consumption of psychoactive substances by school-age children - Youth 2008" realised on behalf of the National Bureau for Drug Prevention with a sample of 1400 students of the last classes of 17-to-18-yearolds covered an age group older than that in the ESPAD study. This revealed that $22 \%$ of respondents declared regular smoking. This is less than in previous research realised between 1992 and 2003 (five editions). An increasing trend was noted until 2003, with $31 \%$ of regular smokers declaring that year [18]. Over the next 10 years, this percentage decreased and stood at $21 \%$ in 2013 . Currently we can speak of a stabilisation of this indicator as in 2016, like in $2013,21 \%$ of respondents regularly smoked cigarettes [19].

The Mokotów study, conducted among 15 -year-olds in schools in the Warsaw districts of Mokotów, Ursynów and Wilanów revealed that, following a period of growth in the 1990s, the first decade of the $21^{\text {st }}$ Century saw a clear reduction in the percentage of young persons who smoked every day. Daily smoking decreased from $10 \%$ in 2012 to around 6\% in 2016 [20]. Bearing in mind the limitations in comparability, it is worth noting that the HBSC study, the one carried out by CBOS (Public Opinion Research Centre) and the Mokotów study confirmed the decreasing trend in smoking among 15-year-olds and older at the beginning of this century.

The situation varied in the other countries selected for comparison. The highest percentage of smokers in the 30 days prior to the study was noted in Italy at $37.1 \%$ and there was an increase in the percentage of young people declaring they had smoked in the last 30 days between 1995 and 2015. Italy was also in first place as far as the prevalence of current smoking was concerned from among all the countries taking part in the ESPAD study, followed by Bulgaria and Croatia with prevalence of $33 \%$.

A spectacular decrease in the percentage of those who reported they had smoked in the 30 days prior to the study was recorded in Norway from $35.5 \%$ in 1995 to $9.7 \%$ in 2015 . This is one of the lowest percentages noted among the European countries taking part in the ESPAD study. It ought however to be born in mind that snus, a nicotine-based product, is very popular in Norway and this is not included in the ESPAD international okresie, bo pomiędzy rokiem 2011 a 2015, odnotowano spadek z $28,4 \%$ do $24,8 \%$.

Inne badanie „Konsumpcja substancji psychoaktywnych przez młodzież szkolną - Młodzież 2008”, zrealizowane na zlecenie Krajowego Biura ds. Przeciwdziałania Narkomanii, objęło 1400 uczniów ostatnich klas szkół ponadgimnazjalnych, a więc młodzież starszą niż ta $\mathrm{z}$ badania ESPAD. Pokazało ono, że regularne palenie zadeklarowało $22 \%$ badanych. Jest to mniej niż w poprzednich badaniach realizowanych w latach 1992-2003 (pięć pomiarów). Do 2003 roku obserwowano trend wzrostowy, w 2003 roku odnotowano 31\% badanych regularnie palących papierosy [18]. W ciągu 10 lat odsetek ten zmniejszył się i w 2013 roku kształtował się na poziomie $21 \%$. Obecnie można mówić o stabilizacji tego wskaźnika, gdyż w 2016 roku (podobnie jak w 2013) regularnie paliło papierosy $21 \%$ badanych [19].

Badanie mokotowskie - prowadzone wśród 15-letniej młodzieży uczącej się szkołach na terenie warszawskiego Mokotowa, Ursynowa i Wilanowa pokazało, że po okresie wzrostu do połowy lat 90 ., w latach dwutysięcznych nastąpiło wyraźne zmniejszenie odsetka młodzieży palącej codziennie. Palenie codzienne zmniejszyło się z 10\% w roku 2012 do około 6\% w 2016 [20]. Pamiętając o ograniczeniach porównywalności, warto zwrócić uwage na fakt, że zarówno badania HBSC, badania prowadzone przez CBOS, jak i mokotowskie potwierdzają trend spadkowy palenia wśród młodzieży w wieku 15 lat i starszej na początku XXI wieku.

W innych krajach wybranych do porównań sytuacja była zróżnicowana. Najwyższy odsetek osób palących w 30 dniach poprzedzających badanie odnotowano we Włoszech (37,1\%) - pomiędzy rokiem 1995 a 2015 nastąpił wzrost odsetka młodzieży deklarującej palenie w ciągu ostatnich 30 dni. Włochy uplasowały się na pierwszym miejscu, jeśli chodzi o rozpowszechnienie aktualnego palenia, wśród wszystkich krajów biorących udział w badaniu ESPAD, na kolejnych miejscach była Bułgaria i Chorwacja $\mathrm{z}$ rozpowszechnieniem na poziomie $33 \%$.

Spektakularne zmniejszenie odsetka osób sięgających po papierosy w ciągu 30 dni poprzedzających badanie zaobserwowano w Norwegii: z 35,5\% w roku 1995 do 9,7\% w 2015. Jest to jeden z najniższych odsetków odnotowanych w krajach europejskich biorących udział w badaniu ESPAD. Trzeba jednak pamiętać o tym, że w Norwegii dużą popularnością cieszy się snus, używka z nikotyną, której używanie nie jest ujmowane w mię- 
report. As other studies have shown, snus use is on the increase in Norway [21], Sweden [22] and Finland [23], with the largest increase observed among young people [21].

Due to the high risk of the development of dependency, a particularly serious problem is early nicotine initiation [24]. Research suggests that dependency risk increases with lower age of initiation $[25,26]$. As far as the trend is concerned, in all European countries participating in ESPAD, the percentage of young people who start smoking at 13 or younger has clearly decreased over the last 20 years. This trend is observed in the majority of countries, with Norway showing the largest decrease from among all the countries analysed in this paper. In Poland, the percentage in this age group decreased from $17.6 \%$ to $10 \%$.

In Poland a National Health Programme is being realised since 1990, which has been developed on the basis of the WHO "Health for all in 2000" strategy. This was the first attempt to involve a variety of different national and local administrative institutions in the protection of public health. A further edition of the National Health Programme from September 1995 included 18 operational goals taking into account risk factors in the prevention of health problems. One of these aims was the limitation of tobacco smoking [27]. A further version of the $\mathrm{Na}$ tional Health Programme for 2007-2015 coordinated by the National Institute of Public Health and the Ministry of Health adopted the reduction of smoking tobacco as a priority aim in the programme section describing risk factors and activity as regards the promotion of health [28].

The Programme for the Prevention of the Health Risks of Smoking in Poland accepted by the Government on the basis of article 4 of the law of $9^{\text {th }}$ November 1995 on the protection of health from the consequences of tobacco and tobacco product use describes in detail the tasks and bodies responsible for carrying them out and also the scope of cooperation between those bodies. Emphasis was place on children's health protection by limiting their exposure to tobacco smoke, eliminating smoking in public spaces, reducing access to tobacco products, guaranteeing support to persons who wish to stop smoking, support- dzynarodowym raporcie ESPAD. Jak pokazuja inne badania, używanie snusu ma charakter zwyżkowy w Norwegii [21], Szwecji [22] oraz w Finlandii [23], a największy wzrost w ciągu ostatnich kilku lat zaobserwowano wśród młodych ludzi [21].

$\mathrm{W}$ związku z wysokim ryzykiem rozwinięcia uzależnienia, szczególnie poważnym problemem jest wczesna inicjacja nikotynowa [24]. Badania sugerują, że ryzyko uzależnienia wzrasta wraz z obniżeniem wieku inicjacji $[25,26]$. Jeśli chodzi o trend, we wszystkich krajach europejskich uczestniczących $\mathrm{w}$ badaniu ESPAD odsetki młodych ludzi, którzy w wieku 13 lat lub mniej sięgają po pierwszego papierosa, zdecydowanie zmniejszyły się na przestrzeni 20 lat. Trend ten można zaobserwować $\mathrm{w}$ większości krajów. Z analizowanych w tym opracowaniu krajów największy spadek osiągnięto w Norwegii. W Polsce odsetek w tej grupie wiekowej zmniejszył się z 17,6\% do 10\%.

W Polsce od 1990 roku realizowany jest Narodowy Program Zdrowia opracowany na podstawie strategii Światowej Organizacji Zdrowia „Zdrowie dla wszystkich w roku 2000”. Była to pierwsza próba zaangażowania w ochronę zdrowia różnych instytucji administracji państwowej i lokalnej. Kolejne wydanie Narodowego Programu Zdrowia, uchwalone we wrześniu 1995 roku, zawierało 18 celów operacyjnych biorących pod uwagę czynniki ryzyka $\mathrm{w}$ zapobieganiu problemom zdrowotnym. Jednym z celów było ograniczenie rozpowszechnienia palenia tytoniu [27]. Kolejna wersja Narodowego Programu Zdrowia na lata 2007-2015, koordynowana wspólnie przez Narodowy Instytut Zdrowia $\mathrm{Pu}$ blicznego i Ministerstwo Zdrowia, przyznała priorytet celowi, jakim jest zmniejszenie rozpowszechnienia palenia tytoniu w części programu opisującej czynniki ryzyka i działania w zakresie promocji zdrowia [28].

Program Ograniczania Zdrowotnych Następstw Palenia Tytoniu w Polsce - przyjęty przez Radę Ministrów na podstawie art. 4 Ustawy z dnia 9 listopada 1995 r. o ochronie zdrowia przed następstwami używania tytoniu i wyrobów tytoniowych - szczegółowo opisuje zadania i podmioty odpowiedzialne za ich wykonanie, a także zakres współpracy pomiędzy nimi. Położono nacisk na ochronę zdrowia dzieci poprzez ograniczenie ekspozycji na dym tytoniowy, wyeliminowanie palenia $\mathrm{w}$ przestrzeni publicznej, ograniczenie dostępności wyrobów tytoniowych, zagwarantowanie pomocy osobom chcącym rzucić 
ing pro-health social attitudes and market control [28].

In 2006, Poland joined the WHO Framework Convention on Tobacco Control, established in Geneva in 2003. The resulting commitments were in accordance with Polish health policy defined in the law on the protection of health from the consequences of tobacco and tobacco product use. A large part of the tasks resulting from the content of the convention is in line with the government programme for the limitation of the health consequences of tobacco smoking. Poland's membership of the convention contributed to the maintaining of beneficial trends in health care and also resulted in certain social groups (those living in poverty, children and young people and pregnant women) receiving special protection [29].

The decreasing trend in tobacco use by young people in Poland is in line with that observed in other European countries [14]. As pointed out by Shibuya et al. [30], these positive changes may, amongst other things, be attributed to the implementation of the recommendations of the WHO Framework Convention on Tobacco Control by the majority of countries [31]. The recommendations with the greatest influence on these positive trends include: information on the harm of tobacco use also printed on tobacco product packaging, limitation of access through the shaping of pricing policy, reducing exposure to tobacco smoke in public places, reducing the possibility of advertising and promoting tobacco products and limiting under-age access to tobacco [14].

The measure that probably played the greatest role in the case of young people was the increase in the price of tobacco products [32]. Guindon et al. describe the reasons for price increases being effective in the case of young people. They indicate among others that young people did not yet develop such a strong dependency as is the case for long-term users and it is easier for them to give up. Secondly, they usually have much more limited funds that they would rather spend on something else [33].

Dudek et al. [34] link the decrease in tobacco use among young people that took place from 2003 with the changes in our country in relation to joining the EU in 2004. These resulted in the adoption of certain legal measures that tightened nicotine policy. palenie, kreowanie prozdrowotnych postaw społecznych oraz kontrolę rynku [28].

W 2006 roku Polska przystąpiła do Ramowej Konwencji WHO o Ograniczeniu Użycia Tytoniu, przygotowanej w Genewie w 2003 roku. Zobowiązania wynikające $\mathrm{z}$ konwencji były zgodne $\mathrm{z}$ polityką zdrowotną Polski określoną $\mathrm{w}$ ustawie o ochronie zdrowia przed następstwami używania tytoniu i wyrobów tytoniowych. Znaczna część zadań wynikających z treści konwencji pokrywała się $\mathrm{z}$ tymi uwzględnionymi $\mathrm{w}$ rządowym programie ograniczenia zdrowotnych następstw palenia tytoniu. Przystąpienie Polski do konwencji przyczyniło się do utrzymania korzystnych trendów w ochronie zdrowia, a także sprawiło, że niektóre grupy społeczne (osoby żyjące w niedostatku, dzieci i młodzież, kobiety w ciąży) zostały objęte szczególną ochroną [29].

Trend spadkowy w używaniu tytoniu przez młodzież w Polsce jest zgodny z trendem zaobserwowanym w innych krajach europejskich [14]. Jak twierdzą Shibuya i wsp. [30], te pozytywne zmiany można m.in. przypisywać wdrożeniu przez większość państw zaleceń wynikających z Ramowej Konwencji WHO o Ograniczeniu Użycia Tytoniu [31]. Do zaleceń, które miały największy wpływ na te pozytywne trendy należą: informowanie o szkodliwości używania tytoniu, także na opakowaniach wyrobów tytoniowych, ograniczanie dostępności poprzez kształtowanie polityki cenowej, ograniczanie ekspozycji na dym tytoniowy w przestrzeni publicznej, ograniczanie możliwości reklamowania i promowania wyrobów tytoniowych, i ograniczanie dostępu osobom niepełnoletnim do tytoniu [14].

Działaniami, które prawdopodobnie odegrały największą rolę $\mathrm{w}$ przypadku osób młodych, było zwiększenie cen wyrobów tytoniowych [32]. Guindon i wsp. opisują powody, dla których zwiększenie cen może być efektywne w przypadku młodzieży. Wskazują m.in., że osoby młode nie zdążyły jeszcze rozwinąć tak silnego uzależnienia, jak ma to miejsce w przypadku długoletnich użytkowników, i łatwiej im zrezygnować z palenia. Po drugie, zwykle dysponują ograniczonym budżetem, który wolą przeznaczyć na inne cele [33].

Dudek i wsp. [34] łączą spadek w używaniu tytoniu wśród młodzieży, który ma miejsce od 2003 roku, z przekształceniami, jakie zaszły w naszym kraju w związku z przystąpieniem do Unii Europejskiej w 2004 roku. Przekształcenia te pociągnęły 
Especially in the case of young people, of significance may be the observed cultural changes involving greater concern for health and external appearance. Public Opinion Research Centre (CBOS) survey for 2016 shows that the belief in the popularity of healthy living has been growing steadily and significantly in Poland [35]. The percentage of respondents noticing symptoms of Poles taking care of their health increased by $13 \%$ between 2012 and 2016 and compared to 1993 it increase more than threefold from $19 \%$ to $64 \%$. Also the percentage of people declaring they care for their own health has been increasing regularly (from 1993 by $27 \%$ inclusive).

It ought however to be noted that not all have been beneficiaries to the same extent of these positive changes. As indicated by Kowalewska et al. [36], young people from families of low socioeconomic status who live in places with a much higher frequency of social problems smoke tobacco much more often.

In future it is worth broadening the study to so-called e-cigarettes and the use of products that contain nicotine like snus, the use of which is widespread in Scandinavia. Without broadening the study to other forms of nicotine use, it is going to be difficult to gain a reliable picture of young person's behaviour related to this psychoactive substance.

\section{- Conclusions}

Current use of tobacco in Poland in 2015 was at $24.8 \%$, which is a decrease in relation to 1999 , the year in which the highest prevalence of $32 \%$ was recorded. This is in line with the results of other studies carried out in Poland. The decreasing trend in the use of tobacco by young people in Poland is also in accordance with the trend observed in other European countries.

It would seem that a consequentially realised policy with the aim of limiting tobacco use brings the desired results in the case of young people. It ought however to be noted that, apart from the policy to limit the availability of tobacco, wider cultural and social changes may here come into play. za sobą m.in. przyjęcie pewnych rozwiązań prawnych zaostrzających politykę nikotynową.

Szczególnie w przypadku osób młodych mogą mieć znaczenie obserwowane zmiany kulturowe polegające na większej dbałości o zdrowie i wygląd zewnętrzny. Badanie CBOS z 2016 roku pokazało, że systematycznie i znacząco rośnie przekonanie o popularności prozdrowotnego stylu życia w Polsce [35]. Odsetek badanych dostrzegających symptomy dbałości Polaków o zdrowie zwiększył się pomiędzy rokiem 2012 a 2016 o 13 punktów procentowych, a w porównaniu z 1993 rokiem wzrósł ponad trzykrotnie (z 19\% do 64\%). Regularnie rośnie także odsetek osób deklarujących dbałość o własne zdrowie (od 1993 roku wzrost o 27 punktów łącznie).

Trzeba jednak zauważyć, że nie wszyscy w jednakowym stopniu są beneficjentami tych pozytywnych zmian. Jak wskazują Kowalewska i wsp. [36], znacznie częściej pali tytoń młodzież z rodzin o niskim statusie socjoekonomicznym oraz zamieszkująca tereny o większym nasileniu problemów społecznych.

W przyszłości badania warto poszerzyć o używanie tak zwanych e-papierosów oraz uwzględnić używki z zawartością nikotyny, takie jak snus, którego używanie jest rozpowszechnione $\mathrm{w}$ krajach skandynawskich. Bez poszerzenia badań o inne sposoby używania nikotyny trudno uzyskać wiarygodny obraz zachowań młodzieży związanych $\mathrm{z}$ tą substancją psychoaktywną.

\section{- WNIOSKI}

Aktualne używanie tytoniu w Polsce w 2015 roku zostało oznaczone na poziomie $24,8 \%$, co oznacza spadek o 7,2 punktu procentowego w stosunku do 1999 roku, kiedy odnotowano najwyższe rozpowszechnienie $-32 \%$. Jest to zgodne $\mathrm{z}$ innymi wynikami badań prowadzonych w Polsce. Trend spadkowy w używaniu tytoniu przez młodzież w Polsce jest również zgodny z trendem zaobserwowanym w innych krajach europejskich.

Wydaje się, że prowadzona konsekwentnie polityka mająca na celu ograniczanie używania tytoniu przynosi pożądane rezultaty $\mathrm{w}$ przypadku młodzieży. Trzeba jednak zauważyć, że oprócz polityki ograniczania dostępności tytoniu, na zachowania związane z jego konsumpcją mogą mieć wpływ szersze zmiany kulturowe i społeczne. 


\section{Conflict of interest/Konflikt interesów}

None declared./Nie występuje.

\section{Financial support/Finansowanie}

Ministry of Science and Higher Education, Core funding for statutory R \& D activities, no 501-002-15008/ 501-002-16008/ 501-002-117008./Ministerstwo Nauki i Szkolnictwa Wyższego, Temat statutowy, nr 501-002-15008/ 501-002-16008/ 501-002-117008.

\section{Ethics/Etyka}

The work described in this article has been carried out in accordance with the Code of Ethics of the World Medical Association (Declaration of Helsinki) on medical research involving human subjects, EU Directive (210/63/EU) on protection of animals used for scientific purposes, Uniform Requirements for manuscripts submitted to biomedical journals and the ethical principles defined in the Farmington Consensus of 1997.

Treści przedstawione w pracy są zgodne z zasadami Deklaracji Helsińskiej odnoszącymi się do badań z udziałem ludzi, dyrektywami UE dotyczącymi ochrony zwierząt używanych do celów naukowych, ujednoliconymi wymaganiami dla czasopism biomedycznych oraz z zasadami etycznymi określonymi w Porozumieniu z Farmington w 1997 roku.

\section{References/Piśmiennictwo}

1. Ustawa z dnia 9 listopada 1995 r. o ochronie zdrowia przed następstwami używania tytoniu i wyrobów tytoniowych. Dz.U. z 1996 r. nr 10, poz. 55, z późn. zm.

2. Raport z ogólnopolskiego badania ankietowego na temat postaw wobec palenia tytoniu. Warszawa: TNS dla Głównego Inspektoratu Sanitarnego; 2015.

3. Tyas SL, Pederson LL. Psychosocial factors in the initiation to smoking among adolescents: a critical review and analysis of the literature. Toronto: The Ontario Tobacco Research Unit; 1997.

4. Cleary PD, Hitchcock JL, Semmer N, Flinchbaugh LJ, Pinney JM. Adolescent smoking: research and health policy. Milbank $Q$ 1988; 66: 137-71.

5. Mazur J, Tabak I, Małkowska-Szkutnik A, Ostaszewski K, Kołoło H, Dzielska A, et al. Czynniki chroniace młodzież 15-letnia przed podejmowaniem zachowań ryzykownych. Raport z badań HBSC 2006. Warszawa: Instytut Matki i Dziecka; 2008.

6. Kowalewska A, Dzielska A. Zachowania ryzykowne młodzieży - współczesne podejście do problemu. Studia BAS 2014; 2: 139-68.

7. Sierosławski J. The ESPAD project: history and assumptions. Introduction to series of papers from the ESPAD study 1995-2015. Poland against the background of Europe. Alcohol Drug Addict 2018; 31(1).

8. Swaim RC. Individual and school level effects of perceived harm, perceived availability, and community size on marijuana use among $12^{\text {th }}$-grade students: a random effects model. Prev Sci 2003; 4(2): 89-98.

9. Unger JB, Shakib S, Cruz TB, Hoffman BR, Pitney BH, Rohrbach LA. Smoking behavior among urban and rural Native American adolescents in California. Am J Prev Med 2003; 25(3): 251-4.

10. Robinson LA, Klesges RC, Zbikowski SM, Glaser R. Predictors of risk for different stages of adolescent smoking in a biracial sample. J Consult Clin Psychol 1997; 65(4): 653-62.

11. Doubeni CA, Li W, Fouayzi H, DiFranza JR. Perceived Accessibility as a Predictor of Youth Smoking. Ann Fam Med 2008; 6(4): 323-30. doi:10.1370/afm.841.

12. Mäkela K, Room R, Single E, Sulkunen P, Walsh B, Bunce R, et al. Alcohol, Society, and the State 1: A Comparative Study of Alcohol Control. Toronto: Addiction Research Foundation; 1981.

13. Babor T, Caetano R, Casswel S, Edwards G, Giesbrecht N, Graham K, et al. Alcohol no ordinary commodity. Research and Policy. Oxford University Press; 2003. 
14. ESPAD Report 2015. Results from the European School Survey Project on Alcohol and Other Drugs. European Monitoring Centre on Drugs and Drug Addiction; 2016.

15. Dublet A, De Bacquer D, Valimaa R, Godetu E, Schmid H, Rahav G, et al. Smoking trends among adolescents from 1990 to 2002 in ten European countries and Canada. BMC Public Health 2006; 6: 280. doi.org/10.1186/1471-2458-6-280 https://bmcpublichealth.biomedcentral.com/articles/10.1186/1471-2458-6-280.

16. Kowalewska A. Palenie tytoniu. In: Mazur J (ed.). Zdrowie i zachowania zdrowotne młodzieży szkolnej w Polsce na tle wybranych uwarunkowań socjodemograficznych. Wyniki badań HBSC 2014. Warszawa: Instytut Matki i Dziecka; 2015.

17. Kowalewska A. Palenie tytoniu. In: Wojnarowska B, Mazur J (eds.). Tendencje zmian zachowań zdrowotnych $i$ wybranych wskaźników zdrowia młodzieży szkolnej w latach 1990-2010. Warszawa: Instytut Matki i Dziecka, Wydział Pedagogiki Uniwersytetu Warszawskiego; 2015.

18. Młodzież a substancje psychoaktywne. CBOS; 2009.

19. Młodzież 2016. CBOS; 2016.

20. Ostaszewski K, Bobrowski K, Borucka A, Okulicz-Kozaryn K, Pisarska A, Biechowska D, et al. Monitorowanie zachowań ryzykownych, zachowań nałogowych i problemów zdrowia psychicznego 15-letniej młodzieży. Badania mokotowskie 2004-2016. Badania ukraińskie, obwód lwowski 2016. Warszawa: Instytut Psychiatrii i Neurologii; 2017.

21. Lund M, Lindbak R. Norwegian Tobacco Statistics 1973-2006. Oslo; 2007.

22. Lundqvist G, Sandstrom H, Ohman A, Weinehall L. Patterns of tobacco use: a 10-year follow-up study of smoking and snus habits in a middle-aged Swedish population. Scand J Public Health 2009; 37: 161-7.

23. Haukkala A, Vartiainen E, De Vries H. Progression of oral snuff use among Finnish 13-16-year-old students and its relation to smoking behaviour. Addiction 2006; 101: 581-9.

24. Nutt DJ, King LA, Phillips LD. Drug harms in the UK: a multicriteria decision analysis. Lancet 2010; 376: 1558-65.

25. Breslau N, Peterson E. Smoking cessation in youth adults: age at initiation of cigarette smoking and other suspected influence. Am J Public Health 1996; 2: 214-20.

26. Everett SA, Warren CW, Sharp D, Kann L, Husten, CG, Crosell LS. Initiation of cigarette smoking and subsequent smoking behaviour among U.S. high school students. Prev Med 1999; 5: 327-33.

27. Narodowy Program Zdrowia 1996-2005. Ministerstwo Zdrowia i Opieki Społecznej. Warszawa; wrzesień 1996.

28. Załącznik do uchwały 90/2007 Rady Ministrów w sprawie Narodowego Programu Zdrowia z 15.05.2007 r.

29. Raport: Stan zagrożenia epidemią palenia tytoniu w Polsce. Światowa Organizacja Zdrowia; 2009.

30. Shibuya K, Ciecierski C, Guindon E, Bettcher DW. WHO Framework Convention on Tobacco Control: development of an evidence-based global public health treaty. BMJ 2003; 327: 154 .

31. Ramowa Konwencja Światowej Organizacji Zdrowia o Ograniczeniu Użycia Tytoniu, sporządzona w Genewie dnia 21 maja 2003 r. Dz.U. 2007 nr 74, poz. 487.

32. Agrawal A, Budney A, Lynskey MT. The co-occurring use and misuse of cannabis and tobacco: a review. Addiction 2012; 7: 1221-33.

33. Guindon GE, Tobin S, Yach D. Trends and affordability of cigarette prices: ample room for tax increases and related health gains. Tob Control 2002; 11: 35-43.

34. Dudek M, Basznia-Kocot J, Giel K. Trendy wybranych zachowań zdrowotnych młodzieży polskiej w wieku 13-15 lat na podstawie wybranych i światowych badań z lat 1995-2011. Medycyna Środowiskowa 2015; 2: 74-80.

35. Zdrowie i prozdrowotne zachowania Polaków. Komunikat z badań. CBOS; 2016.

36. Kowalewska A, Mazur J, Dzielska A, Chełchowska M. Palenie tytoniu przez 15-latków w Polsce w zależności od wybranych czynników socjodemograficznych - tendencje zmian 2006-2014. Przegląd Lekarski 2015; 72 (3): 115-9. 
